\title{
BIOGRAFI TUMENGGUNG JALIL SANG PANGLIMA PERANG BANJAR
}

\author{
Rabi Yati \\ Email: 2010128120009@mhs.ulm.ac.id \\ Program Studi Pendidikan IPS Fakultas Keguruan dan Ilmu Pendidikan \\ Universitas Lambung Mangkurat \\ Banjarmasin
}

\begin{abstract}
Abstrak
Pada tahun 1859-1863 terjadi perlawanan oleh masyarakat Kalimantan Selatan terhadap kolonialisme Belanda, yang melibatkan hampir seluruh masyarakat Kalsel dan tokoh-tokoh pejuang, salah satunya adalah Tumenggung Jalil yang merupakan salah satu panglima perang Banjar yang begitu disegani oleh Belanda. Tumenggung Jalil memiliki peran yang sangat besar dalam Perang Banjar, dimana Ia memegang kendali di daerah Banua Lima hususnya pada daerah Nagara dan Amuntai. Beliau menyusun strategi pertahanan yang kuat dengan mendirikan benteng di sekitar Masjid Amuntai, membuat rintangan dan beberapa pos-pos penjagaan untuk memperkuat pertahanan masyarakat di Banua Lima. Tumenggung Jalil juga tak kenal takut dan berani menyerahkan hidup dan matinya demi mempertahankan tanah kelahirannya sampai titik darah penghabisan. Dengan keberanian dan kepahlawanan beliau inilah yang patut kita ambil contoh dan di jadikan pelajaran, sehingga dibuatlah artikel biografi Tumenggung Jalil ini berdasarkan metode sejarah, yang bertujuan untuk membangun jiwa nasionalisme di dalam diri pembaca melalui kisah tokoh pejuang seperti Tumenggung Jalil.
\end{abstract}

\section{PENDAHULUAN}

Pada masa kolonialisme Belanda terjadi perlawanan atau pemberontakan dibeberapa daerah di Indonesia terhadap penjajahan Belanda. Perlawanan tersebut salah satunya terjadi di daerah Banjarmasin, yaitu pada tahun 1859-1863 yang mana perang ini disebut sebagai perang Banjar. Perlawanan masyarakat Banjar ini membawa kepada peperangan yang memakan waktu panjang, dengan medan perang yang begitu luas. Dimana perang ini dipimpin oleh Pangeran Hidayatullah dengan Pangeran Antasari selaku panglimanya bersama dengan Demang Lehman, Tumenggung Surapati, Tumenggung Jalil, Haji Buyasin, Penghulu Rasyid, Kyai Langlang dan para tokoh-tokoh lainnya yang memiliki peran besar dalam perlawanan ini. 
Walaupun Belanda di dalam peperangan ini berhasil menguasai pusat kota Banjarmasin dan Martapura, namun perang tetep berlanjut dan meluas hingga ke kawasan pedalaman Kalimantan Selatan. Bukan perkara mudah bagi Belanda untuk memenangkan pertempuran ini, dikarenakan pertempuran yang begitu dasyat, medan yang luas dan pasukan yang hampir melibatkan seluruh masyarakat Kalimantan Selatan, sehinngga peperangan ini memakan waktu yang cukup lalma. Perlawanan masyarakat Banjarmasin atau Perang Banjar ini meluas ke beberapa daerah di Kalimantan selatan, daerah-daerah tersebut melipuri daerah Marabahan, Gunung Jabuk, Tabanio, Pulau Petak, Pulau Telo, Sungai Barito dan Banua Lima, yang mana pada setiap daerahnya dibagi beberapa tokoh untuk memimpin peperangan ini. Salah satunaya Pertempuran Banua Liama yang dipimpin oleh Tumenggung Jalil, Pambakal Gafur, Penghulu Abdul Gani, Dulahat dan Duwahap.

Di dalam pertempuran ini tumenggung Jalil selaku salah satu tokoh dalam Perang Banjar, ditunjuk sebagai panglima perang di daerah Banua Lima, hususnya pada daerah Nagara dan Amuntai. Yang mana dengan keberaniannya Tumenggung Jalil dianugerahi gelar Kiayi Adipati Anom Dinding Raja oleh Pangeran Hidayatullah sebagai penghargaan karena telah memihak Kerajaan Banjar. Di percayannya Tumenggung Jalil sebagai panglima perang di Banua Lima bukan tanpa sebab, di utusnya Tumenggung Jalil di Banua Lima melainkan untuk memobilitasi pertempuran di daerah Barito, yang memiliki garis pertahanan yang sulit untuk ditaklukkan oleh Belanda. Salah satu daerah pertahanan masyarakat Banjar ini berada diantara Benteng Penggaron, Benteng Tundukan dan Gunung Tongka yang merupakan garis pertahanan Pangeran Antasari. Tumenggung Jalil dianggap mampu dalam memimpin pertahanan di Banua Lima karena keberanian dan juga kesetiannya terhadap kerajaan banjar yang tertuangkan ke dalam keuletannya dalam menekuni peperangan dengan menyusun strategi dan pertahnan yang kuat dengan membuat pos-pos penjagaan di daerah sekitar Babirik, Alabio dan Sungai Banar.

Dalam pertempuran Tumenggung Jalil menghadapi pasukan Belanda di Benteng Tundukan yang bertepatan pada tanggal 24 September 1861. Bersama dengan tokoh lainnya yaitu Pangeran Antasari, Pangeran Maradipa dan Tumenggunng Baro. Walaupun persenjataan yang kauh lebih minim dibandingkan dengan Belanda, ditambah lagi dengan banyaknya korban yang berguguran, namun Tumenggung Jalil bersama dengan tokoh 
lainnya berhasil memnbuat pasukan Belanda mundur dari medan pertempuran. Namun walau mereka berhasil mempertahankan benteng Tundukan Tumenggunng jalil tewas di dalam pertempuran tersebut, sebagai pahlawan yang mempertahankan Kalimantan seltan dari koloni Belanda.

\section{METODE}

Metode yang digunakan dalam penelitian ini adalah metode kualitatif, berdasarkan metode sejarah pada umumnya yang sesuai dengan kaidah keilmuannya. Yang bertujuan untuk mendapatkan data maupun informasi yang spesifik melalui beberapa tahapan metode sejarah, yakni dimulai dari tahapan heuristik, yaitu pengumpulan sumber-sumber sejarah, yang mana informasi mengenai biografi Tumenggungh Jalil ini didapat melalui buku-buku, jurnal-jurnal, rekam jejak sejaran dan sumber-sumber terpercaya lainnya yang dikumpulkan dan kemudian setelah itu melalui tahapan kritik, yang meliputi tahap kritik eksternal dan internal yaitu tahap validitasi untuk menguji keaslian dan kreadibilitasan sejarah dari beberapa sumber sejarah yang telah diamambil untuk dijadikan acuan dalam pembuatan artikel ini. Setelah melalui tahapan kritik, lalu dilanjutkan dengan interpretasi yakni penafsiran data dan fakta sejarah mengenai Tumenggung Jalil. Setelah interpretasi fakta sejarah kemudian melalui tahapan akhir yakni tahapan historiografi dimana segala faktafakta sejarah mengenai Tumenggung Jalil yang telah dikumpulkan dan melalui beberapa tahapan metode sejarah kemudian dituangkan kedalam artikel ini berdasarkan fakta dan analisis yang telah dilakukan, denagan metode kualitatif, yang mana metode ini menuangkan deskripsi informasi mengenai sejarah tokoh terkait yang di tekiti dan kemudian disusun sedemikian rupa yang bertujuan untuk bahan literasi untuk belajar dari sejarah, memperkaya pengetahuan dan membangun sikap nasionalisme melalui kisah hidup tokoh-tokoh pejuang seperti Tumenggung Jalil.

\section{RIWAYAT HIDUP TUMENGGUNG JALIL DAN KEPAHLAWAN-NYA}

Tumenggung Jalil dengan gelar Tumenggunng Macan Negara dan Kiai Adipati Anom Dinding Raja adalah seorang pahlawan daerah yang merupakavn panglima Perang Banjar dengan basis pertahanan di pedalaman Kalimantan Selatanyaitu Banua Lima yang meliputi daerah Amuntai, Nagara dan sekitarnya. Beliau telah gugur di medan perang dengan 
umurnya yang tergolong masih muda, yaitu umur 21 tahun Beliau syahid dalam pertempuran untuk mempertahankan kedaulatan daerah Kerajaan Banjar pada saat perang di Benteng Tundakan, Balangan, yang bertepatan pada tanggal 24 September 1861 dari kolonialisme Belanda yang ingin meruntuhkan kedaulatan Kerajaan Banjar. Nama Beliau cukup dikenal oleh khalayak ramai karena kepahlawan Beliau yang rela menyerahkan hidup dan juga masa muda Beliau untuk berjuang dalam mempertahankan tanah kelahirannya. Untuk mengapresi kepahlawanan dan juga perjuangan Beliau, nama Beliau diabadikan dan dijadikan nama untuk beberapa jalan di daerah Kalimantan selatan.

Tumenggung Jalil lahir pada tahun 1840 di kampung Palimbangan, Hulu Sungai Utara, Kalimantan Selatandengan nama lahir Beliau yaitu Jalil dan di dalam Barjie dan Jumbawuya (2019:170) disebutkan bahwa diperkirakan nama kelahiran Beliau adalah Abdul Jalil, sedangkan nama Tumenggung Jalil merupkan nama popular Beliau. Sejak kecil Beliau dikenal sebagai seorang yang pemberani dan merupakan pendekar dengan ilmu silatnya yang hebat, yang mana keberanian dan kehebatan Beliau ini masih terlihat hingga Ia beraanjak dewasa. Tumenggung Jalil merupakan seorang jaba yang artinya dalam bahasa Indonesia bukan dari keturunan bangsawan, yang mana Ia merupakan orang kepercayaan dari Pangeran Hidayatullah. Beliau mendapatkan gelar Tumenggung Macan Negara dan kemudian bergelar Kiyai Adipati Anom Dinding Raja yang berikan oleh Pangeran Hidayatullah karena keberanian dan kesetiaannya dalam memihak kerajaan Banjar, selain itu Beliau juga diberikan hadiah oleh kesultanan Banjar berupa tombak yang berhiaskan naga yang melilit gagang tombak. Tumenggung Jalil juga dikenal atau digelari sebagai Kaminting Pindakan yang artinya jagoan atau jawara. Gelar tersebut disematkan kepada Beliau dikarenakan sikap kepahlawan-Nya, dimana pada saat umur Beliau menginjak 20 tahun Tumenggung Jalil ikut serta dalam perlawanan masyarakat banjar terhadap Belanda yang terletak di Desa Tanah Habang, Paliwara, Lampihong, Amuntai, Telaga Silaba, Awayan, Lok Bangkai dan sebagainya.

Tumenggung Jalil merupakan seorang pahlawan yang sangat heroik dalam memperjuangkan tanah kelahirannya. Beliau adalah seorang panglima perang yang begitu andal, terkenal dengan strategi Beliau dalam menyusun kekuatan di daerah kekuasaan yang Beliau kuasai yaitu di wilayah Banua Lima. Beliau menyusun kekuatan dengan mendirikan 
benteng di sekitar Masjid Amuntai, dan juga ranjau-ranjau atau rintangan untuk menghalau pasukan Belanda dengan kapal-kapal yang dibawanya, karena pada zaman dahulu kebanyakan alat transportasi yang digunakan adalah jenis transportasi air dengan memanfaatkan sungai-sungai, dan begitu pula Belanda dengan menggunakan kapal kapal perangnya. Selain membuat benteng dan juga rintangan-rintangan, Tumenggung Jalil juga membuat beberapa pos-pos penjagaan yang terletak di sekitar Babirik, Alabio dan Sungai Banar untuk memperkuat pertahanan masyarakat di Banua Lima.

Namun begitu, Beliau meninggal dunia disaat melakukan perlawanan terhadap Belanda di Benteng Tundakan tanggal 24 September 1861 disaat usia Beliau masih 21 tahun. Beliau bergabung bersama dengan beberapa tokoh lainnya yaitu Tumenggung Baro dan Pangeran Madipa ke Benteng Tundakan yang mana telah ada Pangeran Antasari dan juga tokoh-tokoh pejuang lain. Peralatan perang di Benteng Tundakan terbatas, dimana meriam dan senapan yang tersedia hanya sekitar 30 buah, yang mana apabila dibandingkan dengan peralatan perang Belanda yang banyak dan juga lebih canggih peralatan perang untuk mempertahankan Benteng Tundakan ini jauh lebih kecil, meskipun demikian, dengan kepercayaan diri dan semangat juang masyarakat dalam melakukan perlawaan ini, akhirnya Belanda terpaksa mundur dari medan perang. Meskipun Berhasil melawan Belanda dan mempertahankan Benteng Tundakan dengan keberaniannya yang menerjang pasukan Belanda tanpa kenal takut, akhirnya Tumenggung jalil tewas di dalam medan pertempuran tersebut bersama dengan serdadu Belanda yang di serangnya hingga tewas.

Walaupun Beliau dianggap sebagai pahlawan yang sangat berperan di dalam mempertahankan kedaulatan kerajaan banjar dari kolonialisme Belanda, namun setelah Beliau meninggal di medan pertempuran, tidak seperti makam makam-makam pahlawan pada umumnya yang memiliki tempat khusus ataupun kubah untuk menghormati dan apresiasi terhadap kepahlawanannya, makam Tumenggung Jalil tidak diketahui dimana keberadaannya, karena pada masa itu masih dalam masa peperangan di dalam mempertahankan Benteng Tundakan, yang mana peperangan imi memakan banyak korban baik dipihak warga Banjar maupun dari prajurit Belanda, sehingga untuk memakamkan semua pahlawan yang gugur secara layak sangat tidak memugkinkan. Selain itu, dari beberapa sumber sejarah Banjarmasin dikatakan bahwa tidak ditemukannya makam 
Tumenggung Jalil dikarenakan makam Beliau yang di bongkar kembali oleh kaki tanagn Belanda, lalu tengkorak Beliau di ambil dan disimpan oleh pihak Belanda, sedangkan bagian tubuh lainnya dihancurkan sehingga Beliau tergolong sebagai pahlawan yang tidak memiliki kubur. Hal keji tersebut diilakukan oleh Belanda karena ketidak puasan mereka terhadap kematian Tumenggung Jalil dan juga rasa benci yang meliputi pemerintah Belanda begitu besar karena Tumenggung Jalil merupakan musuh yang kuat dan paling ditakuti hingga membuat Belanda mencari makam tumenggung jalil hingga mendapatkannya, yang mana dalam pencaharian makam Tumenggung Jalil Belanda juga dibantu oleh seorang penghianat yang memberi tahu keberadaan dari makam Beliau.

\section{PERAN TUMENGGUNG JALIL DALAM PERANG BANJAR}

Tumenggung Jalil merupakan salah satu panglima perang pemberani yang terlihat dari gelar Beliau yaitu Tumengung Macan Negara lalu karena kesetiaannya yang memihak kepada Kerajaan Banjar Ia dikgelari sebagai Kiai Adipati Anom Dinding Raja. Beliau memiliki peran yang begitu penting di dalam perjuangan masyarakat Kaliamantan Selatan untuk mempertahankan kedaulatan Kerajaan Banjar dari para kolonial Belanda yang inin membubarkan Kerajaan Banjar. Saat Beliau ditunjuk sebagai panglima perang di daerah Banua Lima, Tumenggunng Jalil begitu mahir dalam menyusun kekuatan, dimana Beliau membuat pertahanan dengan mendirikan beberapa pos-pos penjagaan di sekitar daerah Babirik, Alabio, dan Sungai Banar, Beliau membuat benteng di sekitar Masjid Amuntai, dan

juga membuat rintangan-rintangan yang akan menyulitkan Belanda dan kapal-kapalnya untuk memasuki daerah yang dituju.

Perang di Banua Lima terjadi pada 9 Februari tahun 1860, dimana Belanda yang dipimpin oleh Mayor Gustave Verspijck dengan ratusan serdadu juga pasukan meriamnya menaiki kapal perand Berned dan Admiral van Kingsbergen dari kota Banjarmasin menuju Alabio terkendala karena rintangan-rintanagn yang dipasang oleh Tumenggung Jalil bersama dengan masyarakat lainnya, sehingga Belanda terpaksa untuk mengganti kapal perangnya dengan menaiki perahu yang lebih kecil agar mudah dalam mengarungi sungai. Dan pertempuran pun terjadi di sekitar Mesjid Amuntai, dimana prajurit dan masyarakat keluar dari Masjid Amuntai dengan menggunakan peralatan perang seadanya berupa tombak, 
pedan, parang bungkul, dan mandau. Walaupun dengan peralatan perang seadanya dan tidak selengkap dan semoderen peralatan perang pasuukan Belanda, namun dengan semangat juang dari rakyat yang menggebu-gebu dan dengan gema takbir masyarakat menyerang pasukan Belanda tanpa kenal takut. Dengan dibawah kepemimpinan Matia dan Mathiyassin, dengan pembantu utamanya yaitu Tumenggung Jalil bersama dengan prajurit-prajutit lokal berusaha dipertahankan dengan kokoh Benteng di sekitaran Mesjid Amuntai, mereka menerjang pasukan Belanda dengan gagah berani, dalam pertempuran ini banyak korban yang berguguran dan kampung di dekat peperangan ikut terkena imbasnya seperti kampung Karias, kebakaran melanda rumah-rumah penduduk sekitar hingga ludes termasuk rumah dari Tmenggang Jalil. Sehingga kampung di sekitar peperangan menjadi saksi bagaimana ketegangan dan juga kepahlawanan para tokoh dalam mempertahankan daerahnya dari jajahan Belanda.

Perang terus berlanjut pasukan Pangeran Hidayatullah yang berada di sekitar Barabai ikut bergabung bersama dengan pasukan Tumenggung Jalil di Pantai Hambawang dan berhasil menghalau gerakan pasukan Belanda membuat para serdadu Belanda mundur dari pertempuran. Hingga pada tanggal 15 Mei 1860 Belanda mendatangkan bantuan serdadu Belanda dari Banjarmasin yang datang menggunakan kapal perang Boni menuju sungai Tabalong. Dalam perjalanan menuju sungai Tabalong, serdadu Belanda dihadapkan dengan serangan dari rakyat sekitar, dan setelah Belanda sampai di daerah Tabalong, perang pun tak terelakkan. Perlawanan dari pasukan Tumenggung Jalil yang dibantu oleh masyarakat sekitar yang cukup sengit mengakibatkan Serdadu Belanda terpaksa mundur dari medan perang dan ke daerah Kelua dan Amuntai. selang beberapa hari, Belanda kemudian berhasil menguasai daerah Tabalong pada bulan juni 1860.

Tidak menyerah begitu saja, setelah Belanda berhasil menduduki tabalong, Tumenggung Jalil bersama-sama dengan pasukannya mendirikan benteng diatas bukit yang terletak di Batu Mandi benteng ini dipercayakan Tumenggung Jalil kepada Penghulu Mudin, dan diantara benteng dipasang ranjau juga rintanga-rintangan seperti lubang perangkap, parit-parit dan juga kayu besar yang akan digulingkan sewaktu-waktu dari atas bukuit, dengan tujuan memutus hubunngan serdadu Belanda antara Barabai dan Lampihong. Dikarenakan strategi dari tumenggung Jalil dan pasukannya yang membangun benteng 
beserta dengan ranjau-ranjaunya, banyak korban berjatuhan dari pihak Belanda karena terkena ranjau yang telah dipasang di sekitar benteng. Karena kegagalan Belanda dalam menembus benteng, Belanda kenudian menembaki benteng tersebut dengan meriam bawah.

Selanjutnya Tumenggung Jalil bertugas untuk mempersiapkan pertahanan rakyat di sepanjang jalur sungai Balangan. Benteng batu mandi kemudian di dipersiapkan oleh Pangeran Antasari dan Pageran hidayatullah, dengan mengibarkan bendera meran dan meletakkan dua buah keris bersilang untuk mengelabui serdadu Belanda dan kemudian mengosongkan benteng. dan benar saja Belanda mendatangi Benteng Batu Mandi pada tanggal 13 Oktober 1860 dan kecewa kerena sebelumnya Belanda telah menghadapi beberapa pasukan di dalam perjalanannya, dan setelah sampai mereka melihat bahwa benteng itu kosong.

Setelah memimpin perang di Banua Lima, kemudian Tumenggung Jalil bergabung dengan Pangeran Antasari dan para pejuang lain ke benteng Tundakan dengan Pangeran Maradipa dan Tumenggung Baro dan juga para pejuang lainnya. Dan pada saat pertempuran di benteng Tundakan inilah Tumenggung Jalil tewas terbunuh bersamaan dengan serdadu Belanda yang dibunuhnya. Dengan itu berakhirlah sudah perjuangan Beliau yang begitu heroik di dalam mempertahankan kedaulatan kalimantana selatan dari kekejaman kolonialisme Belanda yang ingin menduduki dan meruntuhkan Kerajaan Banjar. Walaupun Beliau merupakan pahlawan yang tidak memiliki makam, namun kepahlawanan dan juga jasa Beliau masih berada bersama masyarakat Kalimantan Selatan, karena atas jasa Beliau dan para pejuang lainnya lah kita mengenal Kalimantan Selatanyang seperti sekarang.

\section{SIMPULAN}

Perlawanan masyarakat Banjar terhadap kolonialisme Belanda terjadi pada tahun 1859-1863, pertempuran ini memakan waktu panjang, dengan medan perang yang begitu luas. dipimpin oleh Pangeran Hidayatullah dengan Pangeran Antasari selaku panglimanya bersama dengan Demang Lehman, Tumenggung Surapati, Tumenggung Jalil, Haji Buyasin, Penghulu Rasyid, Kyai Langlang dan para tokoh-tokoh lainnya. Tumenggung Jalil dipercayannya sebagai panglima perang di Banua Lima untuk memobilitasi pertempuran di daerah Barito, yang memiliki garis pertahanan yang sulit untuk ditaklukkan oleh Belanda. 
Tumenggung Jalil dianggap mampu dalam memimpin pertahanan di Banua Lima karena keberanian dan juga kesetiannya terhadap kerajaan banjar yang tertuangkan ke dalam keuletannya dalam menekuni peperangan dengan menyusun strategi dan pertahnan yang kuat dengan membuat pos-pos penjagaan di daerah sekitar Babirik, Alabio dan Sungai Banar, mendirikan benteng di sekitar Masjid Amuntai, dan membuat ranjau-ranjau atau rintangan untuk menghalau pasukan Belanda.

Tumenggung Jalil lahir pada tahun 1840 di kampung Palimbangan, Hulu Sungai Utara, Kalimantan Selatan dengan nama lahir Beliau yaitu Jalil. Sejak kecil Beliau dikenal sebagai seorang yang pemberani dan merupakan pendekar dengan ilmu silatnya yang hebat. Tumenggung Jalil merupakan seorang jaba yang artinya bukan dari keturunan bangsawan. Beliau mendapatkan gelar Tumenggung Macan Negara dan kemudian bergelar Kiyai Adipati Anom Dinding Raja yang berikan oleh Pangeran Hidayatullah karena keberanian dan kesetiaannya dalam memihak kerajaan Banjar. Tumenggung Jalil juga dikenal atau digelari sebagai Kaminting Pindakan yang artinya jagoan atau jawara.

Meskipun Berhasil melawan Belanda dan mempertahankan Benteng Tundakan dengan keberaniannya yang menerjang pasukan Belanda tanpa kenal taku, Beliau gugur di medan perang dengan umurnya yang tergolong masih muda, yaitu umur 21 tahun Beliau syahid dalam pertempuran untuk mempertahankan kedaulatan daerah Kerajaan Banjar pada saat perang di Benteng Tundakan, Balangan, yang bertepatan pada tanggal 24 September 1861 dari kolonialisme Belanda yang ingin meruntuhkan kedaulatan Kerajaan Banjar.

Setelah Beliau meninggal di medan pertempuran, tidak seperti makam makammakam pahlawan pada umumnya yang memiliki tempat khusus ataupun kubah untuk menghormati dan apresiasi terhadap kepahlawanannya, makam Tumenggung Jalil tidak diketahui dimana keberadaannya, karena pada masa itu masih dalam masa peperangan di dalam mempertahankan Benteng Tundakan, yang mana peperangan imi memakan banyak korban baik dipihak warga Banjar maupun dari prajurit Belanda, sehingga untuk memakamkan semua pahlawan yang gugur secara layak sangat tidak memugkinkan. Dan karena ketidak puasan mereka terhadap kematian Tumenggung Jalil dan juga rasa benci yang meliputi pemerintah Belanda begitu besar hal ini membuat Belanda mencari makam tumenggung jalil untuk di bongkar kembali, lalu tengkorak Beliau di ambil dan disimpan 
oleh pihak Belanda, sedangkan bagian tubuh lainnya dihancurkan sehingga Beliau tergolong sebagai pahlawan yang tidak memiliki kubur.

\section{REFERENSI}

Abbas, E. W. (2020). Memahami Sejarah (Sebuah Tanggung Jawab).

Barjie B, A (2015). Perang Banjar Barito 1959-1906 (Deskipsi dan Analisis sejarah). Martapura: Pustaka Agung Kesultanan Banjar.

Barjie B, A., \& Jumbawuya, A. (2019). Mozaik Sejarah Banjar. Banjarbaru: Dinas Perpustakaan dan Kearsipan Provinsi Kalimantan Selatan.

Handy, M. R. N., \& Fatimah, S. N. (2019). Biography of Syekh Muhammad Nafis AlBanjari: An Investigation of Value in the Spread of Islam as a Learning Source on Social Studies. The Kalimantan Social Studies Journal, 1(1), 40-50.

Mahmudah, M., Syaharuddin, S., \& Hasanah, M. (2020). Biography of Ruzaidin Noor: Study of The Educational Values as a Learning Resources on Social Studies. The Kalimantan Social Studies Journal, 2(1), 15-21.

Muhammad, A. (2015). 2014. Strategi Demang Lehman dalam Perang Banjar (1859-1862).

Mutiani, M. (2016). Revitalisasi Nilai-Nilai Kepahlawanan Bagi Pelajar di Kota Banjarmasin. In Developing EDUCATION BASED ON NATIONALISM VALUES The Proceeding of International Seminar: Building Education Based on Nationalism Values. UNIVERSITAS LAMBUNG MANGKURAT.

Subiyakto, B. (2019). Pangeran Hidayatullah: Perjuangan Mangkubumi Kesultanan Banjarmasin.

Setyawan, M. A. (2021). PENGARUH KUNJUNGAN WISATA KE SITUS BENTENG TUNDAKAN SEBAGAI SUMBER BELAJAR SISWA KELAS XI DI SMAN 1 PARINGIN. 